\title{
'MYSOLINE' IN THE TREATMENT OF RECALCITRANT IDIOPATHIC MAJOR EPILEPSY IN MENTALLY DEFECTIVE CHILDREN
}

\author{
BY \\ THOMAS A. COUSTON \\ From Baldovan Institution, by Dundee
}

(RECEIVED FOR PUBLICATION MARCH 9, 1954)

The pharmacology of 'mysoline' has been discussed by Adderley and Monro (1953), Bogue and Carrington (1953), Handley and Stewart (1952), and by Smith and Forster (1953). This report is confined to a description of a recent clinical trial of mysoline in the treatment of recalcitrant idiopathic major epilepsy which was carried out at Baldovan Institution, Dundee. Six members of the trial series were children varying in age from 6 years 10 months to 15 years 8 months. These six children have a history of idiopathic major epilepsy dating from infancy and all have proved recalcitrant to various forms of anti-convulsant drug therapy.

The age and sex of the patients are shown in Table 1.

TABLE 1

AGE AND SEX OF PATIENTS

\begin{tabular}{c|cc}
\hline Case No. & Sex & Date of Birth \\
\hline 1 & Female & 13.5 .41 \\
2 & Female & 27.7 .38 \\
3 & Male & 10.7 .45 \\
4 & Male & 10.10 .39 \\
5 & Male & 25.9 .38 \\
6 & Female & 2.5 .47 \\
\hline
\end{tabular}

The number of episodes of grand mal per patient are shown in Table 2.

TABLE 2

NO. OF GRAND MAL EPISODES PER PATIENT

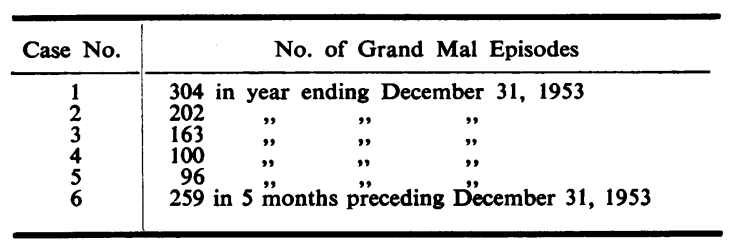

All six patients had received intensive anticonvulsant therapy, and the figures in Table 2 show the best degree of control established at December 31, 1953. Table 3 shows previous anticonvulsant therapy employed at various times before the administration of 'mysoline'.

TABLE 3

SUMMARY OF PREVIOUS TREATMENT

\begin{tabular}{|c|c|}
\hline $\begin{array}{c}\text { Case } \\
\text { No. }\end{array}$ & Previous Treatment \\
\hline $\begin{array}{l}1 \\
2 \\
3 \\
4 \\
5 \\
6\end{array}$ & $\begin{array}{l}\text { 'Epanutin' 'epanutin' and phenobarbitone, 'mesontoin' } \\
\text { 'Epanutin' 'epanutin' and phenobarbitone, 'mesontoin' } \\
\text { 'Epanutin', 'mesontoin', phenobarbitone } \\
\text { 'Epanutin', 'epanutin' and phenobarbitone, 'mesontoin } \\
\text { 'Epanutin', 'epanutin' and phenobarbitone, 'mesontoin' } \\
\text { 'Epanutin', 'mesontoin', phenobarbitone, injection of } \\
\text { soluble phenobarbitone }\end{array}$ \\
\hline
\end{tabular}

The physical and mental condition of each patient was assessed on December 31, 1953. A brief resumé of the condition of each patient is given below.

Case No. 1. A small child of extremely poor physical condition, she has a Meckel's diverticulum which causes her trouble but surgery is contra-indicated because of her physical condition. Her episodes of grand mal are very severe and exhausting. She is confined to bed, is dull and lethargic, takes no interest in her surroundings and makes few voluntary movements.

Case No. 2. This girl is in poor physical condition with a gross deformity of the thorax. She is quite helpless and confined to bed. She has frequent episodes of right cardiac failure precipitated by severe and exhausting episodes of grand mal.

Case No. 3. This epileptic boy is also a case of phenylpyruvic oligophrenia. His physical condition is fair but he is showing a slow deterioration mentally and physically. He is lethargic and shows little interest in his surroundings.

Case No. 4. This boy is in fair physical condition but is showing a marked deterioration both physically and mentally. His episodes of grand mal are severe and followed by long periods of confusion. His scholastic 
abilities have deteriorated to such an extent that he has had to be withdrawn from the school and occupational therapy class. He is moody and irritable, his behaviour is quite unpredictable, and he resents any form of discipline.

Case No. 5. This microcephalic patient is in fair physical condition. His episodes of grand mal are severe and exhausting. He has violent temper tantrums with head banging.

Case No. 6. This little girl has shown a rapid deterioration both physically and mentally since her admission five months ago. Her episodes of grand mal are frequent and severe in spite of intensive anticonvulsant therapy. The degree of control established is slight in spite of high dosage of anticonvulsant drugs. Indeed this dosage is so high that she is lethargic, confused, and clumsy in her movements. She takes little or no interest in her surroundings. She has been withdrawn from school and is now confined to bed.

\section{Scheme of Treatment}

The change-over from the previous anticonvulsant therapy to 'mysoline' was based on a three-unit dose per day time table and was carried out as shown in Table 4.

TABLE 4

TIME-TABLE OF DOSAGE

\begin{tabular}{|c|c|c|}
\hline Day of Treatment & $\begin{array}{l}\text { Previous Treatment } \\
\text { (unit dose) }\end{array}$ & $\begin{array}{c}\text { 'Mysoline' } \\
\text { (unit dose } 0.25 \mathrm{~g} . \text { ) }\end{array}$ \\
\hline $\begin{array}{cc}0-3 & \cdots \\
4-6 & \cdots \\
7-9 & \cdots \\
10 & \text { onwards }\end{array}$ & $\begin{array}{l}3 \\
2 \\
1 \\
\text { Nil }\end{array}$ & $\begin{array}{l}1 \\
1 \\
2 \\
3\end{array}$ \\
\hline
\end{tabular}

Each case was assessed weekly on the bases of (1) general condition, and (2) number of episodes of grand mal.

First Week. During the first week each patient received $2 \mathrm{~g}$. 'mysoline' in addition to a gradually decreasing dosage of the anticonvulsant drug previously administered (Table 4). On the fifth day Case 4 showed an obvious improvement. He appeared more active, more alert and happier. The overall picture in his case resembled that expected from the administration of amphetamine. The other five members of the series showed no change.

Second Week. During the second week each patient received $4.75 \mathrm{~g}$. 'mysoline', and on the tenth day the anticonvulsant drug previously administered was withdrawn (see Table 4). All six patients showed well marked changes in their general condition. Case 1 became obviously more alert, started to sit up in bed voluntarily and made arm and leg movements apparently for her own amusement. Case 2 became brighter and showed interest in her surroundings. Case 3 appeared much more contented and showed an interest in ward life. Case 4 again showed a marked improvement, his whole attitude to ward life changed, he appeared much happier, more contented and amenable to discipline. Case 5 showed a decrease in the number of temper tantrums and his head banging was much less severe. Case 6 exhibited a sudden and remarkable improvement from the eighth day onwards; her lethargy vanished rapidly, she became interested in her surroundings, mental alertness increased, and her muscular coordination became more precise. On the eleventh day she was allowed out of bed and was running about the ward on the fourteenth day. No case showed any side-effects.

Third Week. During the third week each patient received $5 \cdot 25 \mathrm{~g}$. 'mysoline'. In all cases the improvements shown during the previous two weeks were maintained. The outstanding finding was the marked change in mental outlook and personality in all six cases. All showed greater interest in ward life, and appeared much happier and more contented. This was remarkable to witness as all had shown mental and physical deterioration previously.

Fourth Week. During the fourth week each patient received $5 \cdot 25 \mathrm{~g}$. 'mysoline'. Case 1 showed a great increase in muscular activity and in interest in her surroundings. She was allowed out of bed for the first time for four months on the twentysecond day and on the twenty-sixty day she was sitting up in a wheel chair taking a lively interest in her surroundings. Case 2 appeared much more active and contented, her episodes of grand mal were less severe and were not followed by right cardiac failure. Case 3 was much more active, and his lethargy had vanished. Case 4 showed remarkable improvement, he was active, contented, cooperative and amenable to discipline. It was decided to re-admit him to the occupational therapy class the following week. Case 6 showed a similar improvement; she was bright, active and cooperative. It was decided to re-admit her to school.

Fifth Week. During the fifth week each patient received 5.25 g. 'mysoline'. The increase of 'wellbeing' in all six patients was well established and maintained. No relapses had occurred and no side-effects were observed. Case 4 was re-admitted to the occupational therapy class where he settled down and showed an unexpected degree of cooperation and concentration. Case 6 was re-admitted to school where her powers of concentration and ability were found to be superior to those shown when she 
TABLE 5

SUMMARY OF GRAND MAL EPISODES

\begin{tabular}{|c|c|c|c|c|c|c|}
\hline Case No. & Month 1 & Month 2 & Month 3 & Month 4 & Month 5 & $\begin{array}{c}\text { Previous } \\
\text { Monthly Average }\end{array}$ \\
\hline $\begin{array}{l}1 \\
2 \\
3 \\
4 \\
5 \\
6\end{array}$ & $\begin{array}{r}21 \\
14 \\
5 \\
7 \\
2 \\
8\end{array}$ & $\begin{array}{l}12 \\
8 \\
1 \\
1 \\
\text { Nil } \\
\text { Nil }\end{array}$ & $\begin{array}{l}6 \\
8 \\
4 \\
1 \\
\text { Nil } \\
\text { Nil }\end{array}$ & $\begin{array}{l}7 \\
7 \\
2 \\
1 \\
\text { Nil } \\
\text { Nil }\end{array}$ & $\begin{array}{l}4 \\
6 \\
1 \\
\text { Nil } \\
\text { Nil } \\
\text { Nil }\end{array}$ & $\begin{array}{c}23 \cdot 36 \\
15 \cdot 6 \\
12 \cdot 4 \\
7 \cdot 68 \\
7 \cdot 36 \\
51 \cdot 8\end{array}$ \\
\hline
\end{tabular}

was previously withdrawn from school. All cases showed a reduction in the number of episodes of grand mal.

Sixth Week Onwards. Dosage has been maintained at $5 \cdot 25 \mathrm{~g}$. 'mysoline' weekly. The overall picture appears stabilized, and the improvements shown are maintained in all cases. No side-effects have occurred and no relapses have been noted.

Episodes of grand mal have been noted on a 28-day month basis and compared with the 28-day month average number of episodes of grand mal before December 31, 1953, as shown in Table 5.

\section{Conclusion and Summary}

Six cases of recalcitrant idiopathic major epilepsy in mentally defective children have been treated with 'mysoline' over a period of 11 weeks. All six cases had received intensive anticonvulsant therapy previously with other drugs. Each case showed remarkable improvement in a very short period with freedom from side-effects; in one case improvement was noted during the first seven days' treatment.
The improvement in all cases took two forms: (1) personality changes, and (2) decrease in the number of episodes of grand mal.

The personality changes took the form of a great improvement in the general well-being of the patient with increased mental and physical activity and increased powers of concentration with improvement in sociability and performance.

It appears that mysoline has an important place in the treatment of recalcitrant idiopathic major epilepsy in mentally defective children, especially in those showing well marked physical and mental deterioration.

I would like to thank Imperial Chemical (Pharmaceuticals) Limited for supplying the 'mysoline' used in this series.

\section{REFERENCES}

Adderley, D. J. and Monro, A. B. (1953). Lancet, 1, 1154 Bogue, J. Y. and Carrington, H. C. (1953). Brit. J. Pharmacol.,

Handley, R. and Stewart, A. S. R. (1952). Lancet, 1, 742.

Smith, B. and Forster, F. M. (1953). Med. Ann. Distr. Columbia, 22, 279. 